\title{
PENGARUH LAMA PERENDAMAN RUMPUT LAUT Kappaphycus alvarezii TERHADAP NILAI ORGANOLEPTIK SELAI BUAH MANGROVE PEDADA (Sonneratia caseolaris)
}

\author{
Abdul Basir Datunsolang*1; Asri Silvana Naiu; Nikmawatisusanti Yusuf ${ }^{1}$ \\ 1 Jurusan Teknologi Hasil Perikanan, Fakultas Perikanan dan Ilmu Kelautan, Universitas Negeri \\ Gorontalo, Jl.Jenderal Sudirman No.06, Kota Gorontalo 96128, Gorontalo, Indonesia \\ *Korespondensi: abdulbashirdatunsolang@gmail.com \\ (Diterima 06-04-2020 / Dipublikasi 06-04-2020)
}

\begin{abstract}
ABSTRAK
Penelitian ini bertujuan untuk menganalisis tingkat kesukaan panelis terhadap selai buah pedada menggunakan rumput laut $K$. alvarezii yang direndam dengan waktu yang berbeda serta karakteritik mutu selai buah mangrove (Sonneratia caseolaris) rumput laut $K$. alvarezii. Perlakuan pada penelitian ini adalah lama perendaman rumput laut yaitu 1, 2, 3 dan 4 hari. Rancangan analisis organoleptik menggunakan Kruskal Wallis, dan analisis data kimia menggunakan Rancangan Acak Lengkap (RAL). Hasil penelitian menunjukkan bahwa selai mangrove yang menggunakan rumput laut yang direndam dengan lama perendaman berbeda memiliki mutu baik yaitu formula $\mathrm{C}$ (perendaman 3 hari). Lama perendaman rumput laut yang berbeda memberikan pengaruh nyata terhadap nilai mutu hedonik, kimiawi selai mangrove. Karakteristik kimia yaitu kadar serat berkisar antara 6.12\% - 10,63\%; kadar padatan terlarut 63\% - 67,50\%. Serta mutu mikrobiologi TPC yaitu $3,79 \mathrm{CFU} / \mathrm{g}-5,07 \mathrm{CFU} / \mathrm{g}$. Selai yang menggunakan rumput laut yang direndam selama 4 hari tidak memenuhi standar menurut SNI.
\end{abstract}

Kata Kunci : Kappaphycus alvarezii, Karakteristik Mutu, Mangrove Pedada; Selai.

\section{ABSTRACT}

This study aims to analyze the level of preference of panelists on pedada fruit jams using $K$. alvarezii seaweed soaked in different times and the quality characteristics of mangrove (Sonneratia caseolaris) seaweed $K$. Alvarezii. The treatment in this research was seaweed soaking time, which were 1, 2, 3 and 4 days. Organoleptic analysis design uses Kruskal Wallis, and chemical data analysis uses completely randomized design (RAL). The results showed that the mangrove jam using seaweed soaked with different immersion had a good quality, that is formula $\mathrm{C}$ (immersion 3 days). Different soaking times for seaweed have a significant effect on the value of hedonic quality, the chemistry of mangrove jelly. Chemical characteristics, namely fiber content ranges from $6.12 \%$ $10.63 \%$; dissolved solid content $63 \%-67.50 \%$. And the quality of TPC microbiology is $3.79 \mathrm{CFU} / \mathrm{g}$ $5.07 \mathrm{CFU} / \mathrm{g}$. Jelly that uses seaweed that has been soaked for 4 days does not meet the standards according to SNI.

Keywords: Kappaphycus alvarezii, Quality Characteristics, Mangrove Pedada; Jelly. 


\section{PENDAHULUAN}

Pemanfaatan buah bakau (mangrove) tidak sepopuler dibandingkan dengan pemanfaatan kayu batang pohonnya. Pemanfaatan kayu dari batang pohon mangrove digunakan untuk bahan baku pembuatan arang, kayu bakar, dan bahan bangunan. Masyarakat pesisir masih memanfaatkan kayu mangrove untuk ketiga kepentingan tersebut. Hal ini wajar, karena kawasan hutan mangrove merupakan sumber kayu yang penting bagi masyarakat pesisir (Wahyuni, dkk, 2014).

Masyarakat pesisir masih jarang yang memanfaatkan buah mangrove sebagai bahan makanan, minuman/sirup, sabun, lulur dan zat perwarna. Hal ini karena kurangnya pengetahuan masyarakat tentang manfaat buah mangrove, pola pikir (mindset) masyarakat yang menganggap bahwa satusatunya sumber karbohidrat hanya pada beras dan jagung, belum banyak pengetahuan tentang potensi dan manfaat buah mangrove sebagai sumber. Buah mangrove dari berbagai jenis umumnya berpotensi sebagai bahan baku olahan pangan yang saat ini mulai berkembang dengan pesat seperti menjadi sirup, onde-onde, klepon, resoles, kolak, dodol, bolu, kerupuk dan penganan lezat lainnya. Selain itu buah mangrove juga dapat diolah menjadi selai. Jenis buah mangrove yang dapat diolah menjadi selai yaitu antara lain jenis Pedada (Sonneratia caseolaris).
Seiring dengan perkembangan zaman, diversifikasi produk terus dikembangkan untuk meningkatkan daya guna hasil perikanan. Salah satu usaha untuk mengembangkan hasil perikanan tersebut adalah pemanfaatan rumput laut Kappaphycus alvarezzi dalam pembuatan selai buah mangrove pedada sebagai pengental dan penstabil tekstur.

Kappaphycus alvarezii merupakan salah satu jenis rumput laut merah (Rhodophyceae) dan tergolong dalam divisio Thallophyta. Rumput laut jenis K. Alvarezii, tersebar luas di perairan pantai Indonesia dan sudah dibudidayakan secara intensif. Zat gizi yang terkandung dalam $K$. alvarezii antara lain, karbohidrat (39 - $51 \%)$, Protein (17,2 - 27,13 $\%)$, asam lemak esensial, Mineral (K, Ca, $\mathrm{P}$, $\mathrm{Na}, \mathrm{Fe}, \mathrm{I})$, Vitamin (A, B1, B2, B6, B12, C), dan berbagai enzim. Nutrisi yang optimal dalam rumput laut mampu merevitalisasi tubuh, mendukung kesehatan jantung, memperbaiki pencernaan, menguatkan sistem saraf, dan menyeimbangkan hormon (Sulistyowaty, 2009).

Dalam industri pangan $K$. alvarezii banyak digunakan sebagai bahan baku dalam pembuatan dodol, puding, selai, es krim, es buah, cendol, pembuatan mie dan permen jelly. Adanya kandungan gizi yang baik bagi kesehatan pada rumput laut jenis $K$. alvarezii dapat dimanfaatkan sebagai bahan penyusun pengolahan pangan misalnya selai. Selain untuk menambah serat gizi selai, rumput laut 
juga berfungsi sebagai pengental yang dapat memperbaiki tekstur selai mangrove. Pengental pada rumput laut dipengaruhi oleh proses perendaman rumput laut sebelum diolah menjadi produk. Bedasarkan hasil penelitian pendahuluan, diperoleh bahwa kekentalan produk selai dipengaruhi oleh konsentrasi rumput laut yang menjadi bubur. Dengan dugaan bahwa lama perendaman berpengaruh terhadap parameter organoleptik rumput laut, maka perlu diteliti lama perendaman rumput laut untuk memperoleh selai dengan karakteristik organoleptik yang sesuai.

Perendaman rumput laut akan mempengaruhi tesktur rumput laut menjadi lebih lembek dan encer, sehingga akan mempengaruhi tekstur selai. Hal ini sesuai dengan pernyataan Peranginangin et al. (2003) bahwa tujuan perendaman rumput laut dengan menggunakan waktu yang tepat, selain untuk menghilangkan bau amis juga untuk mendapatkan rumput laut yang aseptis dan memiliki tekstur yang lebih kenyal. Berdasarkan hasil penelitian pendahuluan selai mangrove dengan penambahan rumput laut $60 \mathrm{~g}$ menghasilkan selai dengan kriteria warna kecoklatan, tekstur kenyal, aroma dan rasa rumput laut kuat. Penelitian ini bertujuan untuk menganalisis tingkat kesukaan panelis terhadap selai buah pedada menggunakan rumput laut $K$. alvarezii yang direndam dengan waktu yang berbeda serta karakteritik mutu selai buah mangrove (Sonneratia caseolaris) rumput laut $K$. alvarezii.

\section{METODE PENELITIAN}

\section{Waktu dan Tempat}

Penelitian ini dilaksanakan mulai bulan Agustus 2018 sampai Agustus 2019. Pembuatan selai dilakukan di Bolaangmondow Timur Provinsi Sulawesi Utara. Pengujian organoleptik dilakukan di Laboratorium Bioteknologi dan Karakterisasi Hasil Perikanan Jurusan Teknologi Hasi Perikanan Fakultas Perikanan dan IImu Kelautan UNG. Pengujian kimia sampel dilakukan di Pusat Penelitian Sumberdaya Hayati Bioteknologi LPPM Institut Pertanian Bogor.

\section{Alat dan Bahan}

Alat yang digunakan dalam pembuatan selai adalah timbangan digital, kompor, panci, termometer, pengaduk kayu, pisau, baskom plastik dan penyaring. Bahan baku yang digunakan dalam pembuatan selai adalah buah mangrove pedada, rumput laut, gula, air.

\section{Prosedur penelitian}

Penelitian pendahuluan dilakukan untuk mengetahui konsentrasi rumput laut yang digunakan dalam pembuatan selai buah mangrove. Pembuatan formula dilakukan berdasarkan Pakelo (2017) yang dimodifikasi yaitu dengan penambahan rumput laut $K$. alvarezii. Sehingga perlakuan pada penelitian pendahuluan yaitu formula $A(10 \%$ rumput laut), formula $B$ (15\% rumput laut) dan formula C (20\% rumput laut). 
Tahap pembuatan selai yaitu (1) menghaluskan daging buah mangrove yang sudah direndam dengan blender (2) menimbang daging buah yang sudah halus sesuai perlakuan yang akan dilakukan (3) menambahkan bubur rumput laut dan gula (4) mengaduk hingga homogen (5) kemudian memasaknya dengan api sedang pada suhu $60^{\circ} \mathrm{C}$ - 950 $\mathrm{C}$ selama 60 menit sampai mengental dan warnanya sudah kecoklatan (6) mendinginkan dan mengemas selai.

Produk selai terpilih yaitu formula C $(60 \mathrm{~g}$ bubur rumput laut) akan diuji pada penelitian utama. Sebelum ditambahkan pada selai mangrove, rumput laut direndam selama 1, 2, 3 , dan 4 hari. Produk selai yang dihasilkan dikarakterisasi mutu hedonik yang meliputi warna, aroma dan rasa serta karakteristik kimia yaitu kadar serat dan padatan terlarut.

\section{HASIL DAN PEMBAHASAN}

\section{Mutu Hedonik Selai Mangrove Pedada dengan Penambahan Rumput Laut Kappaphycus alvarezii}

\section{Aroma}

Aroma selai menentukan kelezatan selai itu sendiri. Histogram aroma selai mangrove pedada dengan penambahan rumput laut yang direndam dengan lama perendaman yang berbeda dapat dilihat pada Gambar 1 .
(1)

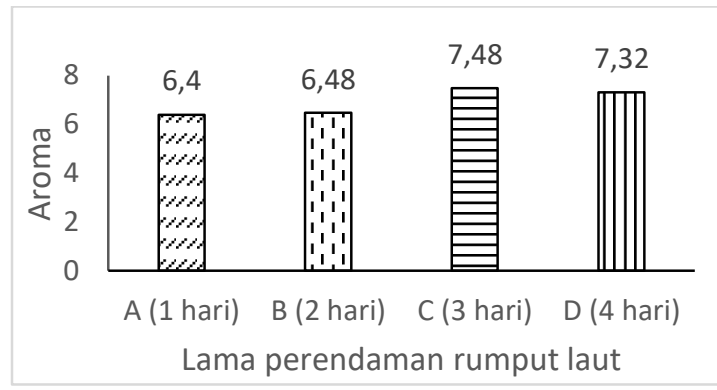

Gambar 1. Histogram aroma selai. Huruf yang sama pada histogram menunjukkan hasil yang tidak berbeda nyata dan sebaliknya.

Gambar 1 menunjukkan nilai organoleptik mutu hedonik aroma selai berada pada kisaran $6,40-7,48$. Nilai mutu hedonik aroma tertinggi terdapat pada formula $\mathrm{C}$ (perendaman rumput laut 3 hari) yaitu 7,48 dengan kriteria aroma mangrove sedikit. Nilai organoleptik terendah terdapat pada formula $A$ (perendaman rumput laut 1 hari) yaitu 6,40 dengan kriteria aroma rumput laut kuat. Selai formula B (perendaman rumput laut 2 hari) memiliki nilai yaitu 6,48 dengan kriteria aroma rumput laut kuat serta formula $D$ (perendaman rumput laut 4 hari) memiliki nilai 7,32 dengan kriteria aroma mangrove sedikit.

Hasil uji Kruskal wallis menunjukkan bahwa lama perendaman berpengaruh nyata terhadap aroma selai yang dihasilkan. Hasil uji Duncan menunjukkan bahwa formula $A$ tidak berbeda nyata dengan $B$, tetapi bebeda nyata dengan formula $C$ dan $D$. Formula $C$ dan $D$ tidak berbeda nyata.

Formula A dan B secara statitik memiliki kriteria aroma yang sama yaitu aroma rumput laut kuat. Sedangkan formula $C$ dan $D$ juga secara statitik memiliki kriteria aroma yang sama yaitu aroma mangrove sedikit. Semakin 
lama perendaman rumput laut aroma selai yang dihasilkan semakin tidak beraroma rumput laut. Hal ini disebabkan karena semakin lama rumput laut direndam, aroma amis rumput laut mulai berkurang. Tujuan perendaman salah satunya untuk menghilangkan bau amis dari rumput laut. Sesuai dengan penelitian Afrianti, dkk (2015) bahwa empek-empek ikan patin dengan penambahan tepung rumput laut masih berbau amis karena hanya dilakukan perendaman rumput laut selama 24 jam (2 hari).

\section{Rasa}

Rasa merupakan atribut sensori yang menentukan penerimaan konsumen, walaupun atribut lainnya memiliki nilai mutu hedonik yang baik, namun jika rasa produk pangan tidak enak, maka produk tersebut tidak diterima oleh konsumen. Histogram rasa selai mangrove dengan penambahan rumput laut yang direndam dengan lama perendaman yang berbeda dapat dilihat pada Gambar 2 .

Gambar 2 menunjukkan nilai organoleptik mutu hedonik rasa selai berada pada kisaran $6,40-7,96$. Nilai mutu hedonik rasa tertinggi terdapat pada formula $\mathrm{C}$ (perendaman rumput laut 3 hari) yaitu 7,96 dengan kriteria rasa khas selai mangrove cukup kuat, terasa manis. Nilai organoleptik terendah terdapat pada formula $A$ (perendaman rumput laut 1 hari) yaitu 6,40 dengan kriteria rasa rumput laut kuat. Selai formula B (perendaman rumput laut 2 hari) memiliki nilai yaitu 6,44 dengan kriteria rumput http://ejurnal.ung.ac.id/index.php/jfpj/issue/archive laut kuat serta formula $D$ (perendaman rumput laut 4 hari) memiliki nilai 7,04 dengan kriteria rasa khas selai mangrove kurang kuat, terasa manis.

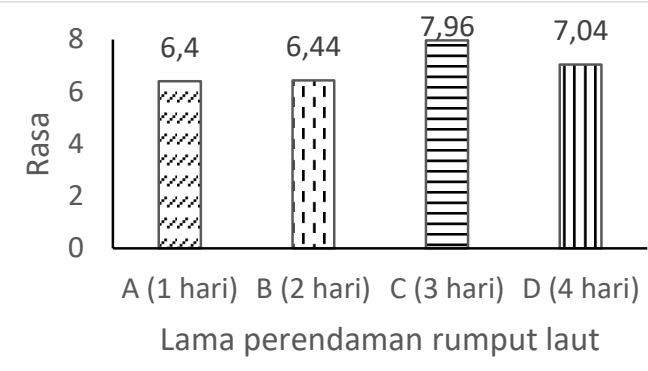

Gambar 2. Histogram rasa selai. Huruf yang sama pada histogram menunjukkan hasil yang tidak berbeda nyata dan sebaliknya.

Hasil uji Kruskal wallis menunjukkan bahwa lama perendaman berpengaruh nyata terhadap rasa selai yang dihasilkan. Hasil uji Duncan menunjukkan bahwa formula A tidak berbeda nyata dengan $B$, tetapi berbeda nyata dengan formula $C$ dan $D$. Formula $C$ dan $D$ berbeda nyata.

Rasa selai mangrove dengan penambahan rumput laut yang direndam dengan lama perendeman yang berbeda menghasilkan rasa yang berbeda. Formula $A$ dan $B$ secara statitik memiliki kriteria rasa yang sama yaitu rasa khas selai mangrove, rumput laut sangat kuat dan manis. Formula $C$ memiliki nilai mutu hedonik 7,96 dengan rasa khas selai mangrove cukup kuat, terasa manis. Serta formula $D$ memiliki nilai mutu hedonik 7,04 dengan kriteria rasa khas selai mangrove kurang kuat, terasa manis. Rasa pada selai diduga dipengaruhi oleh rumput laut yang direndam dengan lama perendaman yang 
berbeda. Semakin lama perendaman rumput laut rasa yang dihasilkan semakin tidak berasa rumput laut. Hal ini disebabkan karena semakin lama rumput laut direndam, rasa khas rumput laut (rasa amis) mulai berkurang.

\section{Tekstur}

Histogram tekstur selai mangrove dengan penambahan rumput laut yang direndam dengan lama perendaman yang berbeda dapat dilihat pada Gambar 3.

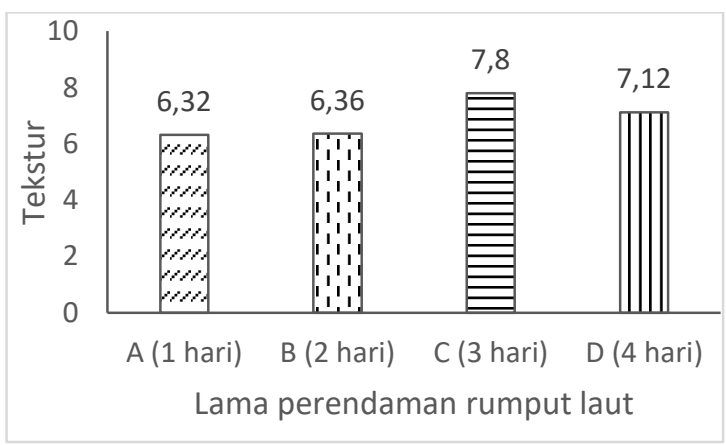

Gambar 3. Histogram tekstur selai. Huruf yang sama pada histogram menunjukkan hasil yang tidak berbeda nyata dan sebaliknya.

Gambar 3 menunjukkan nilai organoleptik mutu hedonik tekstur selai berada pada kisaran $6,32-7,80$. Nilai mutu hedonik rasa tertinggi terdapat pada formula $\mathrm{C}$ (perendaman rumput laut 3 hari) yaitu 7,80 dibulatkan 8 dengan kriteria tekstur lembut. Nilai organoleptik terendah terdapat pada formula $A$ (perendaman rumput laut 1 hari) yaitu 6,32 dengan kriteria tekstur agak keras. Selai formula B (perendaman rumput laut 2 hari) memiliki nilai yaitu 6,36 dengan kriteria tekstur selai agak keras serta formula $D$

http://ejurnal.ung.ac.id/index.php/jfpj/issue/archive (perendaman rumput laut 4 hari) memiliki nilai 7,12 dengan kriteria tekstur agak lembut.

Hasil uji Kruskal wallis menunjukkan bahwa lama perendaman berpengaruh nyata terhadap tekstur selai yang dihasilkan. Hasil uji Duncan menunjukkan bahwa formula $\mathrm{A}$ tidak berbeda nyata dengan $B$, tetapi bebeda nyata dengan formula $C$ dan $D$. Formula $C$ dan $D$ berbeda nyata.

Selai mangrove dengan penambahan rumput laut yang direndam dengan lama perendeman yang berbeda menghasilkan tekstur yang berbeda. Formula A dan B secara statitik memiliki kriteria tekstur yang sama yaitu tidak lembut/agak keras. Formula $\mathrm{C}$ memiliki nilai mutu hedonik 7,80 dengan tekstur lembut, dan formula $\mathrm{D}$ memiliki nilai mutu hedonik 7,12 dengan kriteria tekstur agak lembut. Tekstur pada selai diduga dipengaruhi oleh rumput laut yang direndam dengan lama perendaman yang berbeda. Semakin lama perendaman rumput laut tekstur yang dihasilkan semakin encer/berair.

Tekstur formula D yang tidak lembut/berair diduga karena perendaman yang terlalu lama menyebabkan rumput laut kehilangan sebagian senyawa pengental seperti gum. Gum merupakan serat yang larut dalam air. Sehingga pada saat perendaman rumput laut kehilangan sebagian senyawa gum yang menyebabkan tekstur tidak kenyal. Menurut Glicksman (1982) gum merupakan 
kelompok dari polisakarida pembentuk gel dan bahan pengental larut air. Sesuai pernyataan Peranginangin et al. (2003) bahwa proses perendaman selain untuk menghilangkan bau amis juga untuk mendapatkan rumput laut yang aseptis dan memiliki tekstur yang lebih kenyal.

\section{Mutu Kimiawi Selai Mangrove Pedada}

Hasil pengujian mutu kimiawi selai mangrove dengan penambahan rumput laut yang direndam dengan lama perendaman yang berbeda meliputi kadar serat dan kadar total padatan terlarut yang dapat dilihat pada Tabel dibawah ini.

Tabel 1. Hasil pengujian kimiawi selai

\begin{tabular}{cccccc}
\hline & \multicolumn{5}{c}{ Hasil Penelitian } \\
\cline { 2 - 6 } $\begin{array}{c}\text { Kriteria } \\
\text { Pengujian }\end{array}$ & A & B & C & D & $\begin{array}{c}\text { SNI Selai } \\
\text { Buah }\end{array}$ \\
\hline $\begin{array}{c}\text { Kadar serat } \\
(\%)\end{array}$ & 6,12 & 9,87 & 10,63 & 9,75 & Positif \\
$\begin{array}{c}\text { Kadar } \\
\text { padatan } \\
\text { terlarut (\%) }\end{array}$ & 63,00 & 66,00 & 64,50 & 67,50 & Min 65 \\
\hline
\end{tabular}

\section{Simpulan}

Berdasarkan hasil penelitian dapat disimpulkan bahwa: Selai mangrove yang menggunakan rumput laut yang direndam dengan lama perendaman 1, 2, 3 dan 4 hari, yang memiliki mutu baik yaitu formula $C$ ( 3 hari). Lama perendaman rumput laut yang berbeda memberikan pengaruh nyata terhadap nilai mutu hedonik, kimiawi dan mikrobiologi selai mangrove.

http://ejurnal.ung.ac.id/index.php/jfpj/issue/archive
Karakteristik mutu hedonik selai dilihat dari segi aroma memiliki nilai rata-rata berada pada interval 6,40 - 7,48 dengan kriteria yaitu kriteria aroma rumput laut kuat sampai aroma mangrove sedikit. Rasa memiliki nilai rata-rata berada pada interval 6,40-7,96 dengan kriteria rasa rumput laut sampai rasa khas selai mangrove cukup kuat, terasa manis. Tekstur memiliki nilai rata-rata berada pada interval 6,32 - 7,80 dengan kriteria agak keras sampai lembut.

\section{DAFTAR PUSTAKA}

Badan Standarisasi Nasional. 2008. Selai Buah. SNI 3746:2008. Badan Standarisasi Nasional. Jakarta

Glicksman, M. 1982. Food Hydrocolloids. CRC Press Inc., Florida.

Mustar. 2013. Studi Pembuatan Abon Ikan Gabus (Ophiocephalus striatus) Sebagai Makanan Suplemen (Food Suplement), [Skripsi]. Program Studi IImu dan Teknologi Pangan, Jurusan Teknologi Pertanian, Fakultas Pertanian Universitas Hasanuddin. Makassar.

Pakelo, Fahria. 2017. Formulasi dan Karakterisasi Selai Berbahan Dasar Buah Mangrove (Sonneratia caseolaris). Skripsi. Fakultas Perikanan dan IImu Kelautan. Universitas Negeri Gorontalo. Gorontalo.

Peranginangin R, Bandol BS, Mulyasari. 2003. Teknologi Pemanfaatan Rumput Laut. Badan Riset Kelautan dan Perikanan, Depertemen Kelautan dan Perikanan.

Sulistyowaty, D. 2009. Efek Diet Rumput Laut Kappaphycus alvarezii. Terhadap Glukosa Darah Tikus Wistar Yang Disuntik Aloksan. Karya Tulis IImiah 
Fakultas Kedokteran Universitas Diponegoro. Semarang.

Wahyuni, Y., Putri, E. I. K., Simanjutak, S. M. H. 2014. Valuasi Total Ekonomi Hutan Mangrove di Kawasan Delta Sungai Mahakam Kabupaten Kutai Kartanagara Kalimantan Timur. Jurnal Penelitian Kehutanan Wallacea. 3(1):1-10

Winarno, F. G. 2002. Kimia Pangan dan Gizi. PT Gramedia Pustaka Utama. Jakarta. 